"Mircea cel Batran" Naval Academy Scientific Bulletin, Volume XIX - 2016 - Issue 1

Published by "Mircea cel Batran" Naval Academy Press, Constanta, Romania // The journal is indexed in:

PROQUEST / DOAJ / DRJI / JOURNAL INDEX / I2OR / SCIENCE LIBRARY INDEX / Google Scholar / Crossref /

Academic Keys / ROAD Open Access / OAJI / Academic Resources / Scientific Indexing Services / SCIPIO

\title{
OCCUPATIONAL NOISE EXPOSURE - RISK FACTOR FOR SEAFERARS
}

\author{
Ninela RADULESCU 1 \\ Cecilia ADUMITRESI ${ }^{2}$ \\ Cristina FARCAS ${ }^{3}$ \\ Ileana ION ${ }^{4}$ \\ Eugen RADULESCU 5 \\ ${ }^{1}$ Lecturer, PhD, Physiology Department, Faculty of Medicine \\ 2,3,4 Physiology Department, Faculty of Medicine, "Ovidius" University, Constantza \\ ${ }^{5}$ Capt. Ceronav Center,Constantza
}

\begin{abstract}
Introduction: Professional exposure to noise higher than $85 \mathrm{~dB}$ can lead to hearing diseases (hypoacusia, professional deafness through sound trauma) but, in the same time, also to diseases related to profession (high blood pressure, digestive diseases, neuroses). The measured values of sound intensity within vessel compartmens (engine room, main deck) are different with a higher level in the engine compartment ( $L E X, 8 h=85 \mathrm{~dB}(A))$ Material and method: The survey concerns a batch of 90 navigators (deck and engine crew), selected according to the level of exposure to noise and length of service on the basis of an anamnestic questionnare that apllies to the persons exposed to noise and vibration.
\end{abstract}

Keywords: noise, seafarers, occupational noise, limit exposure level (LEX, 8h), hearing impairment

\section{INTRODUCTION}

Over the last fifteen years, the incidence of hearing defects as the main reason for failure has increased among the seaferars, especially the engine crew.

The aim of the study was to correlate the level of hearing impairment with the intensity of noise for seaferars, on different types of merchant ships of 4 types(oil, container, RO-RO and general cargo), during routine sea voyages, taking in consideration that occupational noise is the most commoncause of noise-induced hearinglossin adults.

According to International Standard Organization (ISO), professional noise is defined as a complex of sounds with various intensities and heights, with different, rhytmical or arythmical characteristics, produced continously or discontinuously, by machines, instruments, devices or human voice, during professional activity.

Particularities of occupational stress to the seaferars are in accordance with the work environment (different for those working at engines and those dealing with navigation on board of the vessels), exposure to intense noise and vibrationes, associated with periodicity and duration of embarkments, length of service and the actual working time on board of marine vessels.

\section{MATERIAL AND METHOD}

This study concerns a batch of subjects (seaferars) that work on board of the vessels, selected according to to the level exposure to noise, vibrationes and length of service on the basis of an anamnestic questionnaire that apllies to all persons exposed to noise and vibrationes.

Risk factors have been studied: exposure to professional emissions, pathological case history related to disorders at the level of the middle ear and administration of toxic medication, neuropsychical symptomatology and subjective tolerance to noise.

Measurements were carried out using the sound level meter NL21 - Rion Japan, coupled with the frecvency analyser at $1 / 1$ and $1 / 3$ octave for the frecvency field $12,5 \mathrm{~Hz}-10 \mathrm{KHz}$, with a homologation certificate as per EEC Model which is valid in Romania according to HG 1055/2001.

Noise level was measured on board of four types of vessels within commercial marine (general cargo, container, RO-RO, oil tank) during voyages at sea and values that exceeded $87 \mathrm{~dB}(\mathrm{~A})$ in some of the vessels compartments were registered.

The survey was carried out on a batch of 90 seaferars (deck and engine crew) attention being paid to: medical history, length of service, actual working time on board of vessels, occupational noise exposure, other occupational exposures, use of hearing protection, periodicity of embarkation and shifts.

Prophylactic medical examinations carried out at the beginning and the end of voyages consisted in: general clinical examinations paying special attention to the cardiovascular system, psychological examination, ear examination and liminal tonal audiometry, by using Amplaid A315 
"Mircea cel Batran" Naval Academy Scientific Bulletin, Volume XIX - 2016 - Issue 1

Published by "Mircea cel Batran" Naval Academy Press, Constanta, Romania // The journal is indexed in: PROQUEST / DOAJ / DRJI / JOURNAL INDEX / I2OR / SCIENCE LIBRARY INDEX / Google Scholar / Crossref /

Academic Keys I ROAD Open Access / OAJI / Academic Resources / Scientific Indexing Services / SCIPIO

audiometer for tonal frequencies between $125 \mathrm{~Hz}$ $-12 \mathrm{KHz}$.

Professional hearing impairment is defined as the permanent drop of the sound threshold at a frequency of $4000 \mathrm{~Hz}$, after applying the presbiacusia correction.

\section{RESULTS AND DISCUSSIONS}

The structure of the batch was: 45 subjects representing the deck navigating personnel and 45 subjects representing the engine crew with the following distribution on age groups: deck crew 7 cases under 35 years, 15 cases between 35 and 40 years, 20 cases between 40 and 45 years, and 3 cases over 45 years old (average 40,45 \pm 5,53 years old); engine crew - 8 cases under 35 years, 12 cases between 35 and 40 years, 17 cases between 40 and 45 years, and 8 cases over 45 years old (average 40,563 $\pm 7,12$ years old) (Table I, Figure 1).

Table I: Case distribution depending on age

\begin{tabular}{|l|l|l|}
\hline Age (years) & Deck crew & Engine crew \\
\hline$<35$ & 7 & 8 \\
\hline $35-40$ & 15 & 12 \\
\hline $40-45$ & 20 & 17 \\
\hline$>45$ & 3 & 8 \\
\hline \multirow{3}{*}{ Total } & 45 & 45 \\
\cline { 2 - 3 } & 90 subjects \\
\hline
\end{tabular}

Distribution of the cases according to length of service groups is the following: deck crew - 3 cases $(6,67 \%)$ under 10 years, 20 navigators $(44,44 \%)$ with a length of service between 10 to 15 years, 20 seaferars $(44,44 \%)$

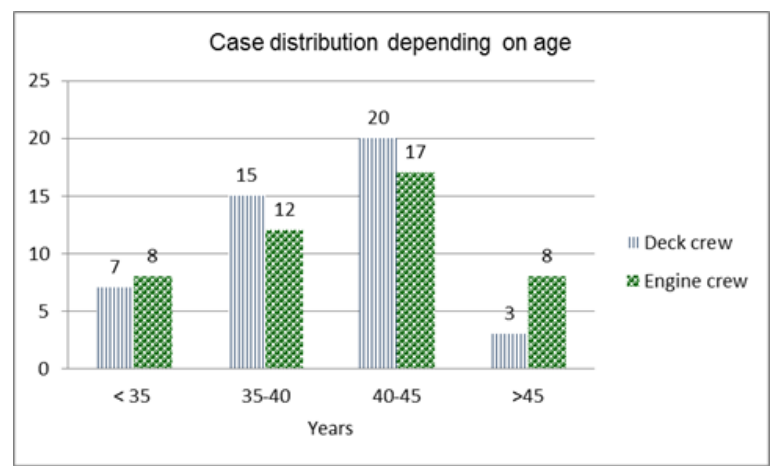

Figure1. Case distribution depending on age

between 15 and 20 years, and 2 seaferars $(4,44 \%)$ with a length of service between 20 and 25 years and no case with a length of service more than 25 years ; engine crew - 5 cases $(11,11 \%)$ under 10 years, 20 navigators $(44,44 \%)$ with a length of service between 10 and 15 years, 15 cases $(33,33 \%)$ between 15 and 20 years, and 5 cases $(11,11 \%)$ with a length of service between 20 and 25 years and no case with a length of service more than 25 years (Table II, Figure 2).

Table II: Case distribution depending on work length

\begin{tabular}{|l|l|l|}
\hline $\begin{array}{l}\text { Work length } \\
\text { (years) }\end{array}$ & Deck crew & Engine crew \\
\hline$<10$ & $3(6,67 \%)$ & $5(11,11 \%)$ \\
\hline $10-15$ & $20(44,44 \%)$ & $20(44,44 \%)$ \\
\hline $15-20$ & $20(44,44 \%)$ & $15(33,33 \%)$ \\
\hline $20-25$ & $2(4,44 \%)$ & $5(11,11 \%)$ \\
\hline$>25$ & - & - \\
\hline Total & $45(100 \%)$ & $45(100 \%)$ \\
\hline
\end{tabular}

High levels of ambient noise, typically above 85 dBA cause noise-induced hearing loss (NIHL). The negative effects of such levels of noise and higher, depend upon individual physiology and the duration of exposure. [9]

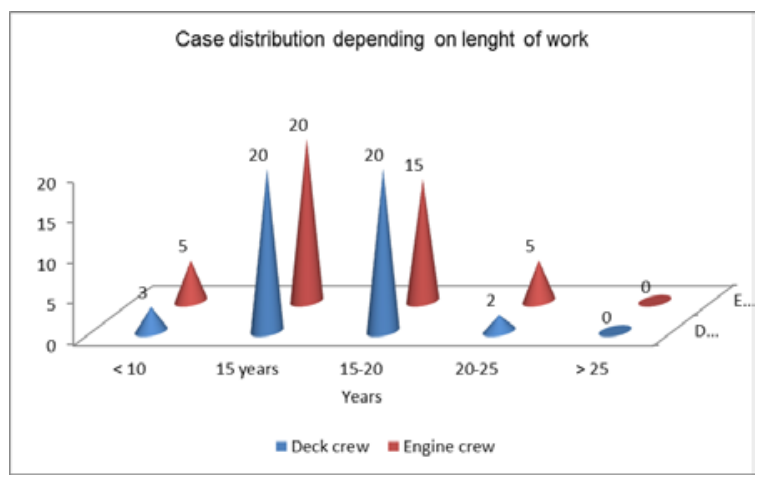

Figure 2. Case distribution according to length of service

The etiological factors that favour the development of hypoacusia are: age, length of service and the actual working time on board of the vessels, pre-existing disorders of the middle ear and ototoxic treatment, alcoholism, smoking, fatigue of the acustic reflex, toxic emissions. The average exposure duration untill the development of the professional hearing disease is of 15 years. $[2,3,5,8]$.The associated risk factors that have been studied are represented in Table III and figure 3 . 
"Mircea cel Batran" Naval Academy Scientific Bulletin, Volume XIX - 2016 - Issue 1

Published by "Mircea cel Batran" Naval Academy Press, Constanta, Romania // The journal is indexed in: PROQUEST / DOAJ / DRJI / JOURNAL INDEX / I2OR / SCIENCE LIBRARY INDEX / Google Scholar / Crossref /

Academic Keys I ROAD Open Access / OAJI / Academic Resources / Scientific Indexing Services / SCIPIO

Table III: Asssociated risk factors

\begin{tabular}{|l|l|l|}
\hline & Deck crew & $\begin{array}{l}\text { Engine } \\
\text { crew }\end{array}$ \\
\hline $\begin{array}{l}\text { Cardiovascular } \\
\text { disorders }\end{array}$ & $4(8,88 \%)$ & $6(13,33 \%)$ \\
\hline Hearing disorders & $1(2,22 \%)$ & $3(6,67 \%)$ \\
\hline Ototoxic treatments & - & $1(2,22 \%)$ \\
\hline Smoking & $38(84,44 \%)$ & $41(91,1 \%)$ \\
\hline $\begin{array}{l}\text { Alcohol } \\
\text { consumption }\end{array}$ & $23(51,1 \%)$ & $28(62,2 \%)$ \\
\hline
\end{tabular}

Simultaneous exposure of the navigating personnel to vibrationes and noise allows the coexistance of hearing changes and vibrationes disease, especially when no means of sound protection are used. $[1,2,7]$

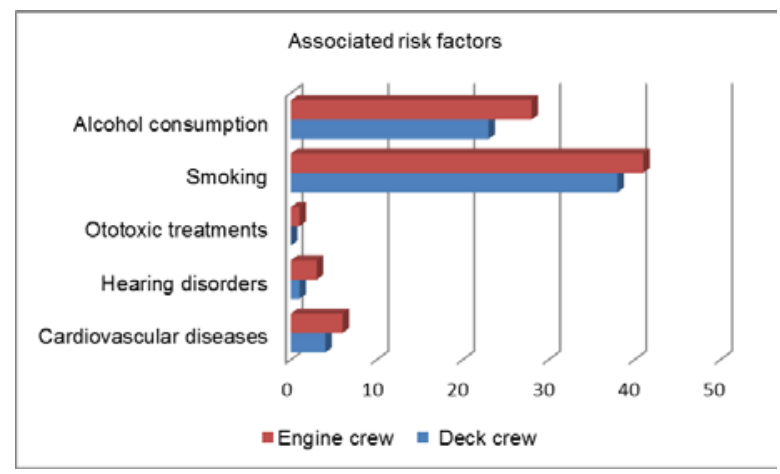

Figure 3. Associated risk factors

The noise level measured on board of the vessels varies (engine more than $85 \mathrm{~dB}$, deck command less than $85 \mathrm{~dB}$, repose areas less than $70 \mathrm{~dB}$ ). The values of the noise registered with the sound level meter on board of the vessels are displayed in figure 4.

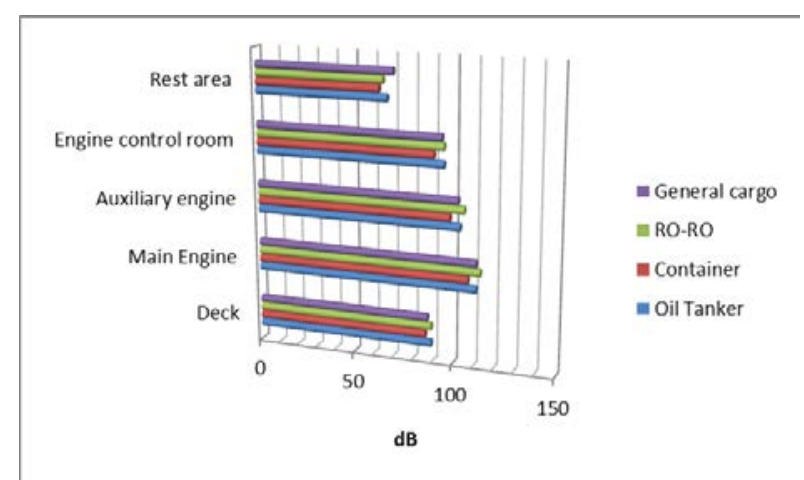

Figure 4.Noise levels registered on board of the marine vessels

Professional hypoacusia is defined as the permanent drop of the sound threshold at a frequency of $4000 \mathrm{~Hz}$ [4, jegaden], with over 30 $\mathrm{dB}$ including, after applying the presbiacusia

DOI: 10.21279/1454-864X-16-I1-082

(C) 2015. This work is licensed under the Creative Commons Attribution-Noncommercial-Share Alike 4.0 License. correction. It is a perception type hypoacusia, generally bilateral and symmetrical, with no interest in conversational frequencies, of professional etiology.[4]

Audiometric determinations carried out at the beginnig and the end of voyages showed that hearing changes is dominant in the band of 3000 - $6000 \mathrm{~Hz}$ octave [4,9]; 53,33\% (24 cases) out of the total number of navigators that were part of the engine crew showed lighthypoacusia, in comparison to $28,9 \%$ (13 cases) out of the total number of the navigators that were part of the deck - command crew; $15,55 \%$ (7 cases) out of the navigators within the engines showed bilateral hypoacusia while at the deck level no case was identified; 2 cases $(4,44 \%)$ of severe hypoacusia among the engine crew and no cases among the deck seaferars;15,55\% (7 cases) out of the total engine crew showed medium hypoacusia; $4,44 \%$ ( 2 cases) out of the deck navigators also showed the same type of hypoacusia; 66,7\% (30 cases) out of the investigated deck crew showed normal hearing, while only $11,11 \%$ (5 cases) out of the engine crew showed normal hearing. (figures 5,6).

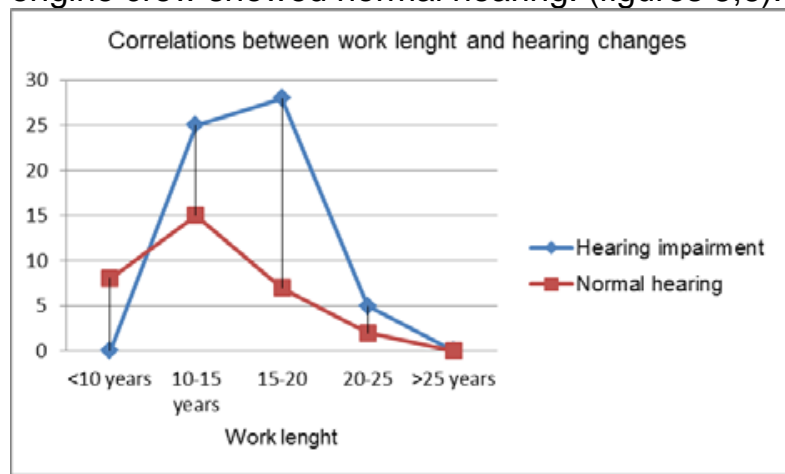

Figure 5. Correlations between work length and hearing changes

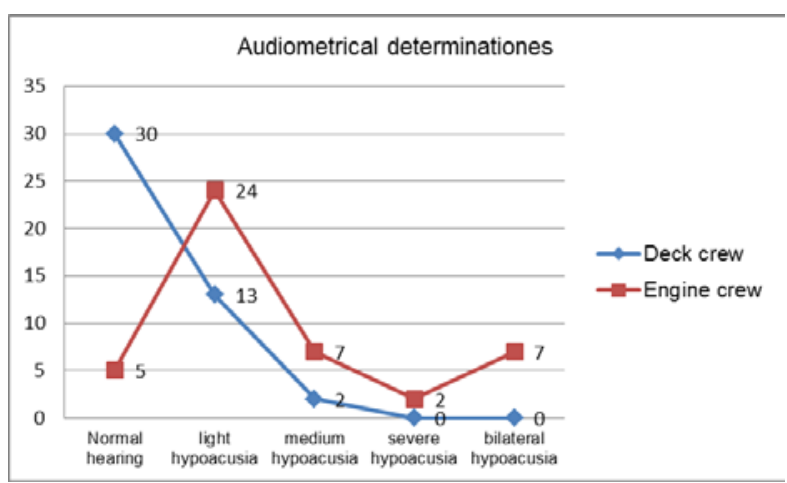

Figure 6. Audiometric determinations

Our study showed a significant difference in the incidence of noise-induced hearing loss between deck and engine crew, also in correlation with the 
"Mircea cel Batran" Naval Academy Scientific Bulletin, Volume XIX - 2016 - Issue 1

Published by "Mircea cel Batran" Naval Academy Press, Constanta, Romania /I The journal is indexed in:

PROQUEST / DOAJ / DRJI / JOURNAL INDEX / I2OR / SCIENCE LIBRARY INDEX / Google Scholar / Crossref /

Academic Keys I ROAD Open Access / OAJI / Academic Resources / Scientific Indexing Services / SCIPIO

length of work onboard marine vessels $(P<0,05) . \quad[1,4,6,9]$.

\section{CONCLUSION}

Regulate exposures to noise greater than 85dBA represents a permanent professional risk for the seaferars; The measured values of sound intensity within vessel compartmens (engine room, main deck) are different with a higher level in the engine compartment, requiring sound protection equipments;

Audiometrical determinations carried out at the beginnig and the end of voyages showed that hearing changes were singnificant especially among engine crew.

\section{BIBLIOGRAPHY}

[1] Kontosic I., Vukelic M. - The prevalence of noise-induced hearing loss in seamen; ArhHigRadaToksikol, 1996Mar;47(1):9-17

[2] Szcepanski C., Otto B. - Evaluation of exposure to noise in seafarers on several types of vessels in Polish Merchant Navy; Bull InstMarit Trop Med Gdynia 1995;46(1-4):13-7

[3] Casson FF., Zucchero A., BoscoloBariga A., Malusa E., Veronese C., Boscolo Rizzo P., Chiereghin F., BoscoloPanzin C., Mancarella P., Mastrangello G. - Work chronic health effects among fishermen in Chioggia, Italy; G Ital Med Lav Ergon, 1998;20(2):68-74

[4] Jegaden D. - Textbook of maritime medicine (Effects on seafarers' hearing), 2013

[5] Hemmingsson T., Lundberg I., Nilsson R., Allebeck P. - Health-related selection to seafaring occupations and its effects on morbodity and mortality; Am J Ind Med; 1997;31(5):662-668

[6] Niculescu T., Todea Adriana, Ion T., Pavel Anca, Niculescu R. - MedicinaMuncii, EdituraMedmun, Bucuresti, 2003

[7] Paucu Elena-Ana - Medicinamuncii, EdituraOrizonturiUniversitare, Timisoara, 2004

[8] Sri H., Heri K. - Noise induced hearing loss in steel factory workers, Folia Medicalndonesiana; vol 40(40) Oct-Dec 2004

[9] http://www.ukpandi.com/loss-prevention/peme/Pre-employment Medical. Examination (PEME) - Limiting noise induced hearing loss in crew(27/01/2016) 